\title{
FACTORS OF SUCCESS IN CASE OF LOCAL SOCIETY
}

Melinda MOLNÁR, PhD, associate professor

Szent Istvan University

Faculty of Economic and Social Sciences

Address: $\quad 2103$ Gödöllő, Páter K. u.1.

Phone: $\quad+36-28 / 522-000$

e-mail: $\quad$ nagyne.molnar.melinda@gtk.szie.hu 


\title{
FACTORS OF SUCCESS IN CASE OF LOCAL SOCIETY
}

Key words: adaptation, local condition, image

\begin{abstract}
The objective of this study is to survey the general success factors of settlements. One can study the following aspects through some example in detail: the local conditions, the innovator seed, to what extent is the management of the settlement authentic, how the relations are synchronised between the innovation seed and the management of the settlement, how the plans for future are embedded in the mind of the local people, how active the local community is, whether there are any positive shadow-effects, what is the accessibility of transportation as well as the internal and external image.
\end{abstract}

\section{INTRODUCTION}

It is generally believed that successful settlements can come into being where the citizens are also prosperous and successful; thus where the growth, the improvement of the quality of life appears also in the life of the community and of the individual. In this case the citizens are obviously content; they can create the properly multilateral and complex expression of interest (Bódi-Bőhm, 2000). However, this scenario cannot be considered as a standard. Interpreting the success of settlements as the set of individual successes is a bit simplifying and idealistic. The individual successes do not always provide clear communal values. There is not in every case a long-term sustainable development behind such a success.

\section{The Interpretation of the Success of Settlements}

Success cannot be reduced to one sole factor. Although in the first place the public opinion interprets the success of the settlements from an economical viewpoint. In fact the success of a settlement is depending on several economical-social factors. The fieldresearch done in settlements also prove this. This essay is based on these research, which were made by Village seminar which exist at the Szent István University, Faculty of Economics and Regional Sciences (Gödöllö, Hungary). The author and her students have been conducting surveys since 2007 in the rural settlements in Kárpátok-basin.

Every factor that influences the local condition of existence and the quality of life has an effect on the development of the settlement, thus also on its success (Ludescher G., 2010). Behind the successful settlements stands a stable economy and community. According to Bartik (1995) and Čapkova (2005) the emphasis is on the positive quality of life besides having a sustainable development. 


\section{Adaptation}

The settlements and the surrounding social, economical sphere are constantly changing. Among the continuously changing conditions those settlements can be truly successful which are able to adapt to their environment. Adapting to the environment can be interpreted in a political, economical, social, technological, nature-geographical and legal sense. The PESTEL analysis is based on the research concerned with the adaptation to the six factors. With this analysis we can get a good general survey about the acting factors. It helps us also in regional planning, because with its help the wanted development goals can be determined more precisely. However, this analysis does not explain, how one can be truly successful through the viewpoint of the examined acting factors. What kind of means can be used for this?

The settlements as autonomies due to their far-reaching role-system possess means of different characteristics, which can strengthen or even weaken each other's effects. One part of the instruments used by the settlements are unique (e.g. local taxes, local communities, etc.), whereas other instruments (e.g. administrative legal regulation) work alike everywhere. The success of a settlement depends also on finding their effective means and how well they use it.

\section{Factors of success}

On the basis of our field experience the following factors can be seen as the factors contributing to the success of the well-working settlements:

- Useful local conditions

- Innovation seed (initiative force)

- Genuine management of the settlement

- Synchronization between the innovation seed and the management of the settlement

- Acceptability of the plans for future in the mind of the local people

- Active local community

- positive shadow-effect

- accessibility of the transportation

- positive internal image

- positive external image 


\section{Figure 1 Factors of Success}

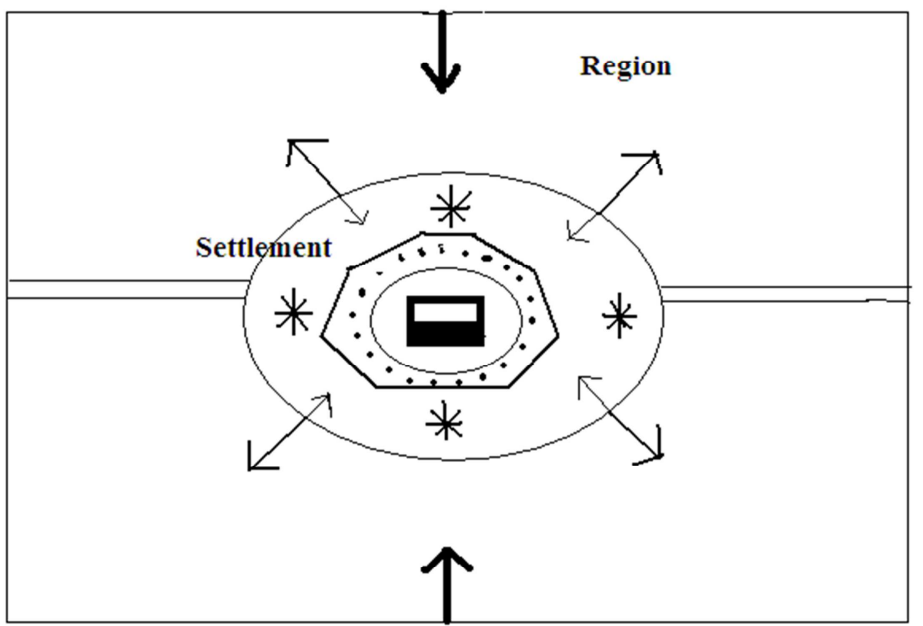

positive shadow-effect

positive external image

positive internal image

acceptability of the plans for future

useful local conditions

genuine management of the settlement

innovation seed

active local community

accessibility of the transportation

synchronization between the innovation seed and the management of the settlement

Source: own editing, 2013

The useful local conditions are such material things, regional circumstances, human resource-elements, which represent unique values in every settlement. To put it into other words, these sources are the settlement's material, mental and spiritual values. The wealth of the settlement can be counted among the material values, including the national wealth and the private means. Due to its nature the national wealth for the most part is nowadays charged with problem-solving and often with mortgage, thus it is difficult to mobilize it. Regarding the private means it can be said that they can be accessed usually only with the approval of the owner. Nevertheless, both kinds of these properties contain the possibility to create value. The typical method of the economical development of the wealth is converting it into money, the burdening, taking into the collective business (PPP constructions). But changing the development possibilities belongs also here, by this means overestimating wealth (e.g. regrading agricultural territories, or the alteration of the building possibilities). Similarly, the settlement's revenues can be regarded as material values, which secure the funds of everyday functioning, but along the proper scheme sources can be detached for other value-creating goals. The local communities' mental capacity and relations capital can be seen as mental values. Among the settlement's mental treasures are for instance the local architectural values, but the local historical values, which were accumulated by the local population can also be counted here. Thus to prosper locally explicit and also tacit knowledge is essential. The settlement's spiritual values are also counted as significant treasures. The genius loci manifest itself alike in the 
architectural environment, in the cleanness of the settlement but also in the speech of the people, their relation to each other and to the guests.

However, the useful local conditions in themselves make no settlement successful. For this result it is necessary to have such an active initiative force, innovation seed, which undertakes to implement the local values in the service of the settlement. It is a lucky situation, when there is synchronization between the innovation seed and the genuine management of the settlement thus they cover each other. This means that shaping the directions of future-serving changes, innovations and the acceptability of the plans for future in the mind of the local people meet in the work of the local management of the settlement thus strengthening each other. It is less lucky and leads often to failure (for instance to by-elections) when the innovation seed and the local management do not support each other. Similarly, crisis can be caused when the social acceptance of the managed innovations is locally modest, namely it has no adequate approval in the local society.

It is a very important, successful determining value of a settlement, to have a "seed" which unites and moves the community and if people representing various interests, values can connect to this. An active local community seed is thus needed. The community's internal structure, dynamics is a value, which can turn into a strategic resource when helping in mobilizing the local economical, social resources. Activities of a narrow core group cannot result in a lasting success if there is no adequate support from the wider community. The communal activity serves properly the success of the settlement only where the whole of the local community or at least the majority of it is supportive.

The so-called "shadow-effect", when evaluating it as the factor determining success we start from the examination of a larger region determining the settlement's success. Our starting-point is that a settlement can be successful if that region, where it exists, is strengthening its efforts, secures support, and it has partners in geographical proximity to exploit the opportunities (Piskóti, 2012). Nevertheless, the shadow-effect works not only in a positive sense but also in a negative one. We can experience this when the settlement possesses extraordinary potential but the medium, with which they are in geographical connection, holds it back, does not let it develop.

Usually the accessibility of transportation is also an important factor of success. It is a fundamental advantage if the economical centres are easily and quickly accessible (with public transport and/or individual transport). The accessibility of the economical centres is a key issue not only for the role of employment in the centre but because the economical 
centre also secures the educational, cultural, health, etc. provision belonging to the higher quality of life.

A settlement can only be successful for long term if it has its own internal image. Namely if people living in the given region has a positive image from their own settlement. Positive image can be built from several factors. This needs adequate community building, well-defined goals; with which everyone can identify themselves. The management of the settlement has to be fully aware of the fact how citizens see their own settlement, what they regard as their strength, their weaknesses, and what are the outside dangers and opportunities.

The external image is also significant from the viewpoint of the settlement's success. It is important that the settlement should be generally known, preferably with a positive content. It cannot be expected from every settlement to have such popularity similar to frequently visited settlements by tourists. Nevertheless, it is important that every settlement should build its external image according to their conditions/opportunities, and to communicate it properly to appropriate group. The external image of the settlements is transmitted partly with conscious communicational activity, partly with the not necessarily controlled common talk. When shaping the external image with conscious communication the aim is to create the settlement's own image, and to learn how to display itself, make it attractive and arouse interest in others.

\section{CONCLUSIONS}

The aim of this study is to throw light upon the following: the success of the settlements is due not only to economical factors. One part of the success factors does not belong to the economic factor, but it can determine the quality of life. Success cannot be reduced to one sole factor.

The settlements and the surrounding social, economical sphere are constantly changing. Among the continuously changing conditions those settlements can be truly successful which are able to adapt to their environment. On the basis of our field experience the following factors can be seen as the factors contributing to the success of the well-working settlements: useful local conditions, innovation seed (initiative force), genuine management of the settlement, synchronization between the innovation seed and the management of the settlement, acceptability of the plans for future in the mind of the local 
people, active local community, positive shadow-effect, accessibility of the transportation, positive internal image, positive external image.

The settlements are value-carriers. Of course not every valuable condition is a key of the success. There is no recipe for the success of settlements. On the particular spot, at the particular time every settlement has its own way to reach its success.

\section{A HELYI TÁRSADALOM SIKERTÉNYEZŐI}

\section{ÖSSZEFOGLALÁS}

E tanulmány célja az, hogy fölhívja a figyelmet: érdemes szakítani azzal a paradigmával, hogy egy település akkor és csak akkor sikeres, ha jól müködő gazdasága van. A sikeresség ugyanis nem pusztán gazdasági tényezökre vezethető vissza.

Általában az a közfelfogás, hogy sikeres települések ott jöhetnek létre, ahol jómódúak, sikeresek a polgárok is; ahol tehát a közösség és az egyén életében is megmutatkozik a gyarapodás, az életminőség javulása (Bódi-Bőhm 2000). Ugyanakkor a települések sikerességének egyéni sikerek halmazán keresztüli értelmezése kissé leegyszerúsítő és idealisztikus. Abban azonban általános az egyetértés, hogy a sikeres települések mögött stabil gazdaság és közösség áll. A hangsúly a pozitív életminőségen és a fenntarthatóságon van (Bartik 1995, Čapkova 2005). Mivel a települések és az őket körülvevő társadalmi, gazdasági tér egyedi, és ráadásul szüntelenül változik is, ezért a siker a konkrét helyen, a konkrét időben minden településen más és más.

A sikerhez az önkormányzatok a szerteágazó szereprendszerükből adódóan több eltérỏ karakterisztikájú, egymás hatását erősíteni és gyengíteni egyaránt képes eszközrendszerrel rendelkeznek. A kérdés az, hogy megtalálják-e, és jól használják-e a hatásos eszközöket. A nyolc éve a Szent István Egyetem keretei között faluszemináriumi keretben zajló, a Kárpát- medencében folyó, falvakat célzó terepi kutatásaink alapján körvonalazódni látszanak a jól müködő települések sikerességéhez hozzájáruló tényezők. E tanulmányban rendszerbe foglalva a következőket emelem ki:

- jól körülhatárolt hasznositható helyi adottságok

Ezek olyan tárgyi (anyagi), táji, humánerőforrás-tartalmak, melyek minden település esetében egyedi értéket képviselnek. Sokfélék lehetnek: anyagi, szellemi, szakrális értékek is.

- innovátor mag (kezdeményezö erö)

Olyan személyek köre, akik aktív kezdeményezö erőként lépnek fel, akik képesek felvállalni a helyi értékek érvényre jutását a település szolgálatában.

- hiteles településvezetés

Olyan településvezetés, akik a település egészét szolgálják, függetlenül attól, hogy felhatalmazásukat nem a falu egészétöl, csak egy részétől kapták.

- az innovátor mag és a településvezetés közötti szinkron

Ez azt jelenti, hogy az innovátor magnak és a településvezetésnek egymást egyértelmüen erösíteni kell: a változások, újítások jövőt szolgáló irányainak kialakítása és a település jövőstratégiajjának kidolgozása során szükségszerúen együtt kell müködniük.

- a äövótervek „,beágyazása” a helyi közösségbe

A jövőtervek beágyazása a helyi közösségbe azt jelenti, hogy a siker érdekében az újitásokat, ötleteket széles körben a helyi társadalommal el is kell tudni fogadtatni.

- tevékeny közösség

Olyan közösség helyben, melyhez a különböző érdekeket, értékeket képviselő emberek is kapcsolódni tudnak.

- pozitív ,shadow-hatás”

Kiindulópontja, hogy egy település nem lehet sikeres, és gazdaságilag sem eredményes akkor, ha az a térség, ahol elhelyezkedik, nem erösíti a törekvéseit, nem biztosít szélesebb értelemben vett kereteket, támogatást számára, $\mathrm{s}$ nincsenek a szomszédban partnerei a megnyíló lehetőségek kihasználására.

- kedvezö közlekedésföldrajzi elérhetöség

A kedvező közlekedésföldrajzi elérhetőség különösen a mindennapi életet meghatározó gazdasági erőközpontok, ellátóközpontok vonatkozásában fontos. Az elérhetőség ugyanis befolyásolja a foglalkoztatást; háttérstruktúrát biztosít a magasabb életminőséget teremtő oktatási, kulturális egészségügyi stb. ellátórendszerekhez.

- $\quad$ pozitív belsö imázs 
Az igazán sikeres települések életében az ott élő emberek képe a saját településükről pozitív. Természetesen ez nem azt jelenti, hogy a mindenki pozitív vélekedése a cél. De törekedni kell arra, hogy mindenki megtalálja a helyét; egészséges, nem negatív jelzőkkel leírható kötődéssel rendelkezzen.

- pozitív külső imázs

A pozitív külső imázs a siker azon eleme, mely azért felel, hogy a település tudatos kommunikációs tevékenységgel megteremtse a saját arculatát, megtanulja önmagát megjeleníteni, mások számára önmagát vonzóvá, érdeklődést felkeltővé tenni.

Azok a települések tudnak igazán sikeresek lenni, amelyek képesek alkalmazkodni a politikai, gazdasági, társadalmi, technológiai, természeti és jogi környezetükhöz. Ezeknek a tényezőknek a változása ugyanis újra meg újra próbára teszi az alkalmazkodóképességet. Így a siker is időről időre átértékelődik.

\section{REFERENCES}

Bartik, T. J. (1995). Economic Development Strategies. Upjohn Institute Working Paper No. 95-33. Kalamazoo, MI: W.E. Upjohn Institute for Employment Research. Retrieved September 17, 2013, from http://research.upjohn.org/up_workingpapers/33

Bódi, F.- Bőhm, A. (2000). A sikeres és sikertelen településekről. (About Successful and Unsuccessful Settlements.) In Bódi F.- Bőhm A (Eds.), Sikeres helyi társadalmak Magyarországon (Successful Local Society in Hungary) (pp. 7-32.). Budapest: Agroinform Kiadóház.

Čapková, S. (2005). Local Government and Economic Development. — Čapková, S. (Ed.), Local Government and Economic Development (pp. 1-19.). Budapest: Open Society Institute.

Ludescher, G. (2010). A vállalkozások és a közösségek szerepe a rurális térségek megújulásában. (Function of the enterprises and communities in connection with regeneration of the rural areas.) Pécs: IDResearch Kft./Publikon Kiadó.

Molnár, M. (2012). Terület- térségmarketing. (Regional marketing.) ISBN 978-615-518379-9 Debrecen: Debreceni Egyetem Agrár- és Gazdálkodástudományok Centruma.

Piskóti, I. (2012). Régió és településmarketing. (Regional and Settlement marketing.) Budapest: Akadémiai Kiadó. 